Hutch', after she was successfully treated there in 1992.

"Unfortunately, Ms. Landro is unable to separate her own experience as a patient from her duties as a journalist," Fancher wrote in The Seattle Times.

From there, the tussle escalated, even though editors at both papers say that The Wall Street Journal is not competing with "Uninformed consent" for a Pulitzer in the investigative reporting category.

On 25 March, The Wall Street Journal published a letter from Fancher in which he accused the Hutch of failing to enact reforms of its clinical-trials oversight process that had been recommended by a review committee. He also said the Food and Drug Administration had found problems with the centre's informedconsent process and shut down three clinical trials there in June 2001.

The Wall Street Journal then devoted an unsigned editorial to an attack on "Uninformed consent" on 27 March. The editorial accused The Seattle Times of sexism and ambulance-chasing. It implied that the paper had not published a previous letter from Landro because the letter would have had to be included in the Pulitzer submission. It also ran a series of letters from scientists and doctors criticizing The Seattle Times series.

On The Wall Street Journal's editorial page, editors claimed that far more is at stake than just a prize for journalists. "We have long felt that medical research needs to be liberated, not inhibited," they wrote.

Some science journalists say that they are concerned that The Seattle Times series was not as thorough or as scientifically rigorous as it should have been.

B. D. Colen, winner of a Pulitzer Prize and faculty member of the graduate programme in science writing at the Massachusetts Institute of Technology, says that the first instalment of the series did not give complete information about the different stages of clinical research, or where the Hutch's experiments fitted into these stages.

But despite the criticism levelled at the series, some observers are defending it on the grounds that the award of the Pulitzer would encourage more investigative reporting into science and medicine.

Another Pulitzer winner, Deborah Blum, president-elect of the National Association of Science Writers, says that she has not read the series. But she welcomes it, saying that there is too little investigative journalism into science and medicine.

"It does not bother me at all that a local newspaper made a cancer centre angry in its investigation," Blum says. "Especially with clinical trials, it's such a good thing to get inside them and try to make people understand what they are about."

\title{
Online tumour bank aims to offer ready route to tissues
}

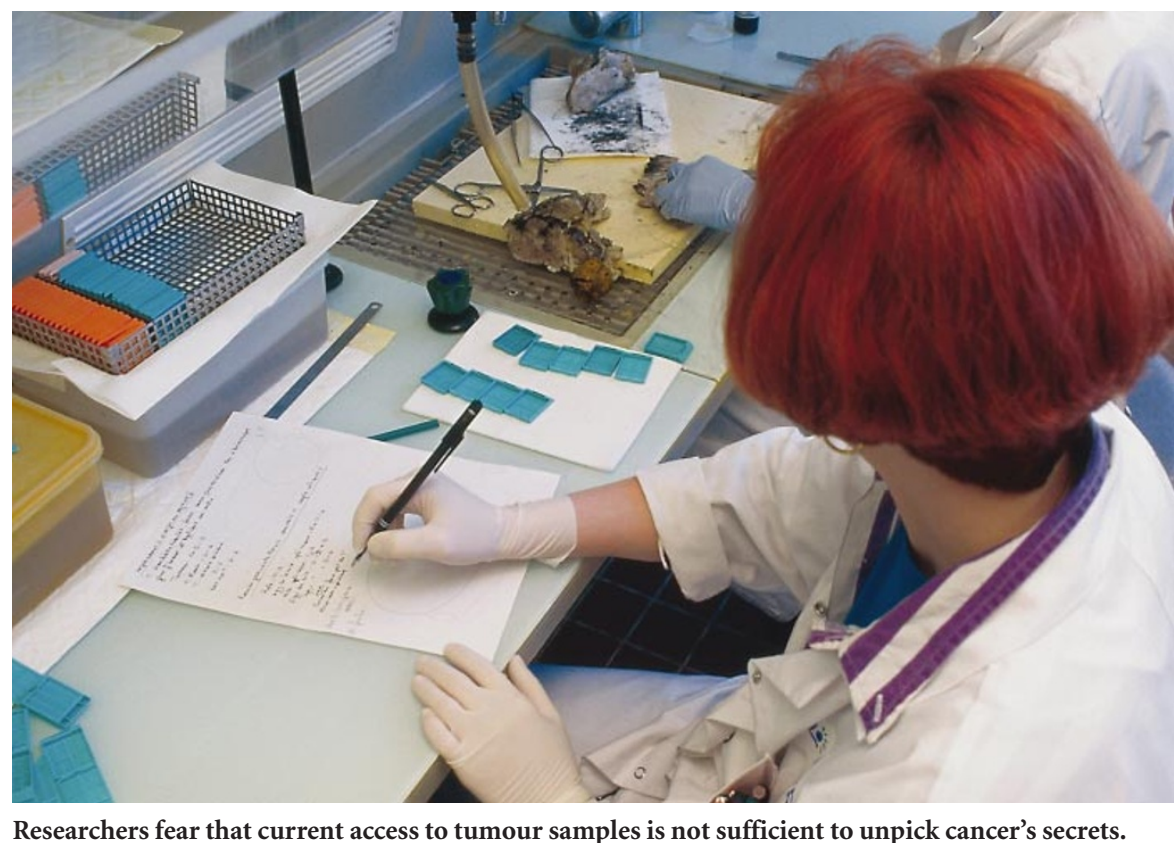

David Adam, London

It is a pathological paradox: how to meet cancer researchers' increasing demand for human tissue while public concern about its use reduces the amount available.

Last week the European Organisation for Research and Treatment of Cancer (EORTC) unveiled its solution - an online library of tens of thousands of tumour tissue samples held at research centres and tissue banks across Europe.

Under plans discussed at last month's EORTC conference in Brussels, participating researchers would browse through samples online and take enough tissue and associated clinical data to carry out molecular profiling and clinical trials. The frozen samples would be stored at the respective centres, and a representative section then scanned and entered into the virtual library.

"By making more tissue more easily available to scientists we can speed up translational research tremendously," says Wolter Oosterhuis, a pathologist at University Hospital Rotterdam who is leading the project.

An increase in both regulation and public scrutiny of the use of research tissue is making access to some materials increasingly difficult. Nick Lemoine, a cancer researcher at London's Hammersmith Hospital, says that supplies of tissue "almost dried up" in some parts of Britain following a series of high-profile scandals over retention of human tissue without consent. Others say that a shortage of pathologists and a tendency to take smaller amounts of material during each biopsy have made some tumour tissue harder to obtain.
The plans are at an early stage, but Oosterhuis is hopeful that the system can be up and running within four years. It builds on a similar EORTC initiative to digitize thousands of slides of tissue samples to create a virtual tumour-tissue bank. Such slides allow physical comparison between samples, but fresh tissue is more useful as it allows investigation of DNA, RNA and protein expression, which researchers believe will shed light on genetic contributions to cancer (see page 470).

Eight cancer centres in France, the Netherlands, Spain, Austria and Britain have signed up to the scheme, although some centres have refused to take part. "Scientists are not easily separated from their materials," Oosterhuis says, "but we argue that by making it available to others you get access to many more samples than you can ever collect yourself.'

The move comes as some researchers express concern that the existing network of tissue banks cannot meet the growing demand for materials. "There has been a huge expansion of molecular analysis on the basis of the genome and we need to provide the materials for this tissue analysis to be done," says Mike Stratton, who heads the Cancer Genome Project at Britain's Sanger Centre near Cambridge.

Some countries, such as the United States and Spain, already link the contents of local banks into a national network. Others are setting up centralized national facilities for tumour tissue. In Britain, a generic tumourtissue bank that will ultimately contain some 3,000 samples from 23 different cancers is expected to open at the University of Glasgow by the end of this year. 